\title{
A meta-analysis of dry matter intake in Nellore and Zebu-crosses cattle
}

\section{José Augusto Gomes Azevêdo1, Sebastião de Campos Valadares Filho², Douglas dos Santos Pina $^{3}$, Mario Luiz Chizzotti ${ }^{3}$, Rilene Ferreira Diniz Valadares ${ }^{4}$}

${ }^{1}$ DCAA/Universidade Estadual de Santa Cruz. Membro do INCT em Ciência Animal.

${ }^{2}$ DZO/Universidade Federal de Viçosa. Pesquisador do CNPq e Coordenador do INCT em Ciência Animal.

${ }^{3}$ DZO/Pós-graduação em Zootecnia - UFV.

${ }^{4}$ DVT/Universidade Federal de Viçosa. Pesquisadora do CNPq e membro do INCT em Ciência Animal.

ABSTRACT - The study was carried out to develop and to evaluate new equations to predict dry matter intake (DMI) of Nellore and Zebu-crosses cattle using meta-analysis procedure. The data used to estimate the parameters were collected from independent performance experiments using growing and fattening Nellore and Zebu-crosses cattle, and they were compiled from 561 experimental units. Before proposing an equation to predict DMI, it was observed that the genetic group was a source of statisticaly significant variation. Therefore, equations to predict dry matter intake in the Zebu-Crosses and Nellore cattle were independently developed. The regression equations for Zebu-crosses cattle were: DMI $=-2.6098+$ $0.08844 \mathrm{BW} 0.75+4.4672 \mathrm{ADG}-1.3579 \mathrm{ADG} 2$ and DMI $=-1.0094+0.01608 \mathrm{BW}+4.4363 \mathrm{ADG}-1.2548 \mathrm{ADG} 2$. The regression equations for Nellore cattle were: DMI $=-2.7878+0.08789 \mathrm{BW} 0.75+5.0487 \mathrm{ADG}-1.6835 \mathrm{ADG} 2$ and DMI $=-1.3559+$ 0.0159BW + 5.6397ADG - 1.8494ADG2. In order to evaluate fitted equations, it was utilized data from independent experiments published from 2005 to 2008 in the Revista Brasileira de Zootecnia. The equations (DMI) for Nellore overpredicted dry matter intake for estimates lower than 7 and higher than $10 \mathrm{~kg} \cdot \mathrm{d}-1$. For Zebu-crosses cattle, dispersions of $3 \mathrm{~kg} \mathrm{~d}-1$ were observed when extreme intakes were evaluated, however, when the equation included BW 0.75 , the intercept did not differ from zero and the slope did not differ from 1. It is not possible to fit only one equation for preditcting DMI for beef cattle in tropical conditions, because there are differences between Zebu and Zebu-crosses. Fitted equations that include ADG and BW 0.75 should be used as an alternative method to predict dry matter intake of Zebu-crosses and Nellore beef cattle in tropical conditions.

Key Words: beef cattle, feed intake, prediction equations

\section{Meta-análise do consumo de matéria seca em bovinos Nelore e mestiços}

RESUMO - Objetivou-se desenvolver e avaliar novas equações para predição do consumo de matéria seca (CMS) em bovinos Nelore e mestiço, utilizando-se meta-análise. Os dados utilizados para estimar os parâmetros foram coletados em experimentos de desempenho independentes com bovinos Nelore e mestiço nas fases de recria e engorda, compilados a partir de 561 unidades experimentais. Antes de propor uma equação para predizer o CMS, observou-se que o grupo genético foi uma fonte de variação estatisticamente significativa. Neste sentido, equações para predizer o CMS em bovinos Nelores e mestiços foram desenvolvidas de forma independente. As equações de regressão para bovinos mestiços foram: CMS = $-2,6098$ + 0,08844PV0,75 + 4,4672GMD - 1,3579GMD2 e CMS = -1,0094 + 0,01608PV + 4,4363GMD - 1.2548GMD2. As equações de regressão para bovinos Nelore foram: CMS $=-2,7878+0,08789$ PV0,75 + 5,0487GMD - 1,6835GMD2 e CMS $=-1,3559$ + 0,0159PV + 5,6397GMD - 1,8494GMD2. Para avaliar as equações ajustadas, utilizaram-se dados de experimentos independentes publicados entre 2005 e 2008 na Revista Brasileira de Zootecnia. As equações (CMS) para Nelore superestimaram o CMS para estimativas menores que 7 e maiores que $10 \mathrm{~kg} \mathrm{~d}-1$. Para bovinos mestiços, as dispersões de $3 \mathrm{~kg} \cdot \mathrm{d}-1$ foram observadas quando pontos extremos foram avaliados, no entanto, quando a equação incluiu PV0,75, o intercepto não diferiu de zero e a inclinação não diferiu de 1. Não é possível ajustar uma única equação para predizer o CMS para bovinos de corte em condições tropicais, porque há diferenças entre Nelores e mestiços. Equações ajustadas que incluem GMD e PV0,75 devem ser usadas como um método alternativo para predizer o CMS em bovinos Nelores e mestiços em condições tropicais.

Palavras-chave: consumo de ração, equações de predição, gado de corte

Received October 23, 2008 and accepted December 2, 2009

Corresponding author: augustog@uesc.br 


\section{Introduction}

Numerous quantitative intake prediction models have been developed, nevertheless, none has achieved widespread acceptance and none uses a universally applicable and robust prediction model (Pittroff \& Kothmann, 2001). Optimally, beef cattle producers should develop intake prediction equations that are specific to give production situations; such equations should account for a greater percentage of the variation in intake than would be possible with a generalized equation (NRC, 2000).

The National Research Council guidelines for beef cattle production (NRC, 2000) have been used in Brazil to formulate diets and evaluate feeding programs. However, these equations were developed mostly with Bos taurus cattle, with a size scaling procedure that is used to adjust differences in mature animal size. In addition, although anabolic stimulants are prohibited in Brazil, they were used in some of the cattle in the database employed to generate the dry matter intake model proposed by the NRC (2000).

When the main purpose of predictive models of dry matter intake is to p redict the concentration of each nutrient in total dry matter intake, the concentration of net energy for maintenance (NEm) in the diet should not be an input variable of model. In order to estimate the content of energy and other nutrients in the diet, it is necessary to initially predict the DMI. Moreover, the nutritional requirements of the animal are primarily determined by the body weight (BW; Plegge et al., 1984), and this, in turn, is dependent on its performance (NRC, 1987). Thus, the residual feed intake, used in the genetic improvement of feed efficiency, is used to predict the feed intake of each animal using an equation with $\mathrm{BW}^{0.75}$ and average daily gain (ADG) (Kolath et al., 2006).

Researchers have gathered data from multiple published studies and attempted to formulate a quantitative model that best explains the reported observations. Generally, there are significant differences among studies; if these differences are not taken into account, they can result in a bias in the estimation of parameters (slopes and intercept) of regression models. Therefore, a meta-analysis, which incorporates the Study effect and its interaction as random components of a mixed model, must be used. This should result in better prediction equations of biological systems and a more accurate description of their prediction errors (St-Pierre, 2001).

This study was carried out to develop and evaluate new equations for dry matter intake prediction in Nellore cattle and Zebu-crosses using a meta-analysis procedure.

\section{Material and Methods}

The data used to estimate the parameter were collected from independent performance experiments that evaluated growing and fattening Nellore and Zebu-crosses (Nellorex Bos taurus) cattle. The data recorded for each observation included sex (SEX), initial body weight (iBW), final body weight, days on feeding (DOF), dry matter intake, and average daily gain (ADG). All data were obtained from feedlot Nellore and Zebu-crosses cattle that were individually fed ad libitum. Only data of bulls and steers were used.

The initial dataset had 32 theses (studies) with 845 experimental units (n, individual cattle). Five thesis (study) with 284 observations were rejected due to data duplication or because they did not meet the initially criteria for selection established for the meta-analyses. This dataset that met the criteria for inclusion in this study was compiled from 27 theses (Table 1) and resulted in 561 observations.

Initially, the significance of the effects of genetic group (GG) and its interactions were calculated and tested statistically by ANOVA, using either body weight (BW) and metabolic body weight $\left(\mathrm{BW}^{0.75}\right)$ as dependent variable of dry matter intake. The model used included terms for body weight (BW and $\mathrm{BW}^{0.75}$ ), average daily gain (ADG) and average daily gain quadratic $\left(\mathrm{ADG}^{2}\right)$ and the interactions with genetic group. The effects of independent variables were considered significant $(\mathrm{P}<0.15)$.

An equation development was conducted in PROC MIXED by using mixed-model regression techniques (St-Pierre, 2001). The study was defined as the subject of the random effect term. Independent variables were initially fitted to a model that included a fixed intercept and slopes and random effects of study in the intercepts and slopes, using an unstructured variance-(co)variance matrix (UN option). When the random slope-intercept covariance term was not significant $(\mathrm{P}>0.10)$ or when the models that included slope-intercept covariance did not converge, option VC (variance components structure) in PROC MIXED was used. Akaike's information criteria (AIC) and Bayesian information criteria (BIC) were used to define the best variance-(co)variance matrix.

The independent datasets used to evaluate the DMI prediction equations for Nellore and Zebu-crosses were provided by eight and twenty-two studies, respectively, from articles published between 2005 and 2008 in the Revista Brasileira de Zootecnia and Boletim de Indústria Animal, both Brazilian publications. The selected experiments were those reporting treatment means for all variables considered in the model selection process. 
The evaluation of the model was performed by linear regression analysis between the observed and the predicted values of dry matter intake, which is a statistical test widely used in model evaluation, and through the analysis of residual or prediction errors (difference between observed dry matter intake and predicted dry matter intake) vs. dry matter intake observed plots (Draper \& Smith, 1981). Mayer $\&$ Butler (1993) recommended to plot observed vs. predicted data, since they can be directly and easily visualized from the graph. Therefore, both types of plots were used for visual evaluation.

The observed data was used as the ordinate and model predictions as the abscissa. In addition, the intercept and the slope were calculated by regression of residues (observed - predicted DMI) on mean-centered predicted DMI. For this evaluation purpose, the tested null hypothesis was the one in which the intercept and the slope, simultaneously, did not differ from zero and unity, respectively (Mayer et al., 1994). In the models, when slope and intercept values were equal to unity and zero, respectively, the model was deemed statistically similar to the data observed $(\mathrm{P}<10)$.

Mean proportional bias was calculated as the slope of the regression of the predicted data on the observed data with a zero intercept (Shah \& Murphy, 2006). A mean proportional bias $<1$ indicates an under-prediction across the range of observed values, and a value $>1$ indicates overprediction (Roseler et al., 1997).

To evaluate model precision, a number of commonly used deviance measures were employed, including root mean square error (RMSE), mean absolute error (MAE) and mean square prediction error (MSPE), as proposed by Picard \& Cook (1984).

The concordance correlation coefficient (CCC; Lin, 1989), also known as the reproducibility index, was used because it has been suggested to simultaneously account for accuracy and precision. It can be expanded into two components, the first one is the correlation coefficient estimate (r), which measures precision, and the second $(\mathrm{Cb})$ is the bias correction factor, which indicates how far the regression

Table 1 - Summary of the thesis data for meta-analysis used in the development dry matter intake equation

\begin{tabular}{|c|c|c|c|c|c|c|}
\hline Study & Reference & $\begin{array}{c}\text { Cattle, } \\
n\end{array}$ & $\begin{array}{l}\text { Days on } \\
\text { feeding }\end{array}$ & $\begin{array}{l}\text { Genetic } \\
\text { group }\end{array}$ & Roughage & Sex \\
\hline 1 & Albuquerque (1972) & 6 & 98 & Crossbred & $\begin{array}{l}\text { Sugar cane, Sorghum silage } \\
\text { and common bean straw }\end{array}$ & Bull \\
\hline 2 & Salvador (1980) & 30 & 144 & Crossbred & Molasses grass hay & Bull \\
\hline 3 & Margon (1981) & 31 & 144 & Nellore & Molasses grass hay & Steers \\
\hline 4 & Lorezoni (1984) & 22 & 216 & Crossbred and Nellore & $\begin{array}{l}\text { Molasses grass hay } \\
\text { and sorghum silage }\end{array}$ & Bull \\
\hline 5 & Teixeira (1984) & 47 & 242 & Crossbred and Nellore & $\begin{array}{l}\text { Molasses grass hay } \\
\text { and corn silage }\end{array}$ & Bull \\
\hline 6 & Galvão (1991) & 34 & 143 & Crossbred & Brachiaria decumbens hay & Bull \\
\hline 7 & Peron (1991) & 13 & 146 & Crossbred & Elephantgrass hay & Steers \\
\hline 8 & Jorge (1993) & 23 & 118 & Nellore and Crossbred & Brachiaria decumbens hay & Bull \\
\hline 9 & Paulino (1996) & 10 & 114 & Nellore & Brachiaria decumbens hay & Bull \\
\hline 10 & Oliveira (1998) & 25 & 126 & Nellore & Coastcross bermudagrass hays & Bull \\
\hline 11 & Gesualdi Jr. (1999) & 38 & 164 & Crossbred & Coastcross bermudagrass hays & Bull \\
\hline 12 & Resende (1999) & 23 & 123 & Crossbred & Tanzaniagrass hay & Bull \\
\hline 13 & Véras (2000) & 25 & 125 & Nellore & $\begin{array}{l}\text { Coastcross bermudagrass and } \\
\text { Brachiaria decumbens hay }\end{array}$ & Bull \\
\hline 14 & Fernandes (2001) & 22 & 80 & Nellore and Crossbred & Coastcross bermudagrass silage & Bull \\
\hline 15 & Silva (2001) & 19 & 112 & Nellore & Tifton 85 bermudagrass hays & Bull \\
\hline 16 & Veloso (2001) & 28 & 171 & Crossbred & Coastcross bermudagrass hays & Bull \\
\hline 17 & Paulino (2002) & 14 & 100 & Nellore & Tifton 85 bermudagrass hays 85 & Steers \\
\hline 18 & Putrino (2002) & 21 & 246 & Nellore & Corn silage & \\
\hline 19 & Backes (2003) & 8 & 129 & Crossbred & Tifton 85 bermudagrass hays & Steers \\
\hline 20 & Leonel (2003) & 8 & 156 & Nellore & Brachiaria decumbens hay & Bull \\
\hline 21 & Miranda (2005) & 3 & 117 & Nellore and Crossbred & Corn silage & Bull \\
\hline 22 & Paulino (2006) & 20 & 105 & Nellore & $\begin{array}{l}\text { Corn silage and } \\
\text { Elephantgrass silage }\end{array}$ & Steers and bull \\
\hline 23 & Chizzotti (2007) & 12 & 111 & Nellore and Crossbred & Corn silage & Bulls and steers \\
\hline 24 & Marcondes (2007) & 9 & 84 & Nellore & Corn silage & Steers and bull \\
\hline 25 & Rigueira (2007) & 13 & 79 & Crossbred & Soybean silage & Bull \\
\hline 26 & Vieira (2007) & 20 & 84 & Crossbred & Mombaçagrass silage & Bull \\
\hline 27 & Marcondes (2010) & 37 & 74 & Nellore and Crossbred & Corn silage & Steers and Bull \\
\hline
\end{tabular}


line deviates from the slope of unity. The location shift (u) relative to the scale is the squared difference of the means relative to the product of two standard deviations.

All statistical analyses were carried out by using SAS (version 9.1, SAS).

\section{Results and Discussion}

The results of the ANOVA indicated that the GG was a significant source of variation for all of the traits of interest (Table 2). Therefore, different equations to predict DMI for Zebu-crosses and Nellore cattle should increase the accuracy. In addition to possible breed-specific effects, NRC (1987) reported that genetic selection for feed efficiency could produce animals with increased feed intake potential, suggesting that genetic potential for growth may affect feed intake.

Table 2 - Summary of ANOVA: significance of the variables and the interaction effects of genetic group $(\mathrm{GG})$

\begin{tabular}{|c|c|c|c|c|}
\hline \multirow[t]{2}{*}{ Item } & $\mathrm{F}$ & P-value & $\mathrm{F}$ & P-value \\
\hline & \multicolumn{2}{|c|}{$\begin{array}{l}\text { Metabolic body } \\
\text { weight }\left(\mathrm{BW}^{0.75}\right)\end{array}$} & \multicolumn{2}{|c|}{$\begin{array}{c}\text { Body } \\
\text { weight (BW) }\end{array}$} \\
\hline $\begin{array}{l}\text { Metabolic body } \\
\text { weight }\left(\mathrm{BW}^{0.75}\right)\end{array}$ & 377.53 & $<.0001$ & & \\
\hline Body weight (BW) & & & 393.70 & $<.0002$ \\
\hline Average daily gain (ADG) & 84.59 & $<.0001$ & 128.04 & $<.0001$ \\
\hline $\mathrm{ADG}^{\mathrm{l}}$ & 30.07 & $<.0001$ & 38.44 & $<.0001$ \\
\hline Interaction with GG & & & & \\
\hline $\begin{array}{l}\text { Metabolic body } \\
\text { weight }\left(\mathrm{BW}^{0.75}\right)\end{array}$ & 4.76 & 0.0297 & & \\
\hline Body weight (BW) & & & 4.95 & 0.0266 \\
\hline Average daily gain (ADG) & 4.49 & 0.0347 & 4.78 & 0.0293 \\
\hline $\mathrm{ADG}^{1}$ & 2.14 & 0.1443 & 2.43 & 0.1198 \\
\hline
\end{tabular}

${ }^{1}$ Quadratic average daily gain.

Table 3 - Descriptive statistics of the dataset used on the development of dry matter intake prediction equations to Zebu-crosses $(n=201)$ and Nellore $(n=360)$

\begin{tabular}{|c|c|c|c|c|c|c|c|}
\hline Item & Genetic group & Minimum & Maximum & Mean & Median & Mode & SEM \\
\hline Dry matter intake $\left(\mathrm{kg} \cdot \mathrm{d}^{-1}\right)$ & Zebu-crosses & 2.83 & 12.00 & 8.11 & 8.17 & 7.79 & 0.108 \\
\hline \multirow[t]{2}{*}{ Inital body weight (kg) } & Zebu-crosses & 151.05 & 450.00 & 324.58 & 328.70 & 360.00 & 4.294 \\
\hline & Nellore & 139.00 & 497.00 & 308.56 & 321.35 & 270.00 & 3.748 \\
\hline \multirow[t]{2}{*}{ Final body weight (kg) } & Zebu-crosses & 213.88 & 584.00 & 440.29 & 448.55 & 540.00 & 4.309 \\
\hline & Nellore & 205.98 & 606.59 & 435.90 & 452.84 & 477.00 & 4.243 \\
\hline \multirow[t]{2}{*}{ Body weight (kg) } & Zebu-crosses & 196.94 & 504.50 & 382.44 & 387.40 & 453.00 & 3.939 \\
\hline & Nellore & 172.88 & 538.33 & 372.23 & 391.98 & 330.00 & 3.699 \\
\hline \multirow[t]{2}{*}{ Metabolic body weight (kg) } & Zebu-crosses & 52.57 & 118.80 & 88.82 & 88.22 & 85.45 & 0.857 \\
\hline & Nellore & 47.68 & 113.26 & 87.19 & 89.65 & 113.26 & 0.670 \\
\hline \multirow[t]{2}{*}{ Dry matter intake (\%BW) } & Zebu-crosses & 1.28 & 2.75 & 2.12 & 2.16 & 2.23 & 0.018 \\
\hline & Nellore & 1.03 & 2.85 & 2.10 & 2.09 & 2.44 & 0.019 \\
\hline \multirow[t]{2}{*}{ Average daily gain $\left(\mathrm{kg} \cdot \mathrm{d}^{-1}\right)$} & Zebu-crosses & 0.02 & 1.95 & 1.00 & 0.99 & 0.86 & 0.030 \\
\hline & Nellore & 0.01 & 1.68 & 0.90 & 0.94 & 1.25 & 0.020 \\
\hline Days on feeding & Nellore & 55.00 & 271.00 & 149.57 & 144.00 & 242.00 & 3.041 \\
\hline
\end{tabular}

Over the years, research in Brazil has suggested that Zebu-Crosses have greater DMI than Nellore cattle (Menezes \& Restle, 2005). Furthermore, it is well established that Holstein steers have a greater DMI than beef steers of similar initial weight; therefore, the NRC (2000) recommended that DMI would be increased $4 \%$ for Holstein vs. beef crosses, and $8 \%$ for Holsteins relative to other beef breeds. The higher DMI by Holstein steers compared to beef breeding steers may be due to a high maintenance energy demand. Holstein cattle have a higher proportion of organ and gut, which increases its metabolic rate (Jones, 1985).

All data used (Table 3) were from experiments that had a minimum duration of 50 days; an adaptation period was insured to minimize the impact of compensatory growth on DMI. Fox et al. (1972) found that compensating steers consumed $16 \%$ more feed than continuous growth steers when re-fed on a corn-based diet.

All the fitted equations exhibited a negative coefficient for the variable $\operatorname{ADG}^{2}\left(\mathrm{~kg} \cdot \mathrm{d}^{-1}\right)$; this indicates that the DMI reaches a plateau (Table 4), which might be directly related to the energy concentration of the diet. Starting from the gains that occur at maximum DMI, the energy demand will be supplied by a low fiber/high energy diet which will reduce the DMI, as it was suggested by the theory of intake regulation for the energy demand (Mertens, 1994). Because of the importance of this effect, NRC (2000) included the variables NEm and $\mathrm{NEm}^{2}$ for the adjustment of equations for DMI.

However, because of the inherent difficulty in accurately determining the net energy content of the diet, Thornton et al. (1985) developed an equation to predict dry matter intake throughout the feeding period, which includes initial body weight and days on feeding. The dry matter intake predicted 
by this equation accounts for $50 \%$ of the variation observed in dry matter intake. The feed intake is typically represented in the overall shape of a dry matter delivery curve for a feedlot pen, with dry matter intake initially increasing to a peak and then decreasing as days on feeding increases due to the increase in body fat content of animals in the feedlot pen.

A simulation of dry matter intake behavior based on the fitted equations was performed (Figure 1), and the relationship of average daily gain and dry matter intake $(\mathrm{g} / \mathrm{kg} \mathrm{PV0.75})$ can be observed. When dry matter intake is expressed in $\mathrm{g} / \mathrm{kg} \mathrm{BW}^{0.75}$, the fitted equations with respect to average daily gain exhibit a dry matter intake curve with three distinct segments: adaptation; plateau; and decline phases, which correspond to adaptation to the feedlot environment, increasing body weight, and increasing body fat content.

However, given the shape of the dry matter intake curve, nutrient requirements during different phases of the finishing period may differ greatly for cattle in tropical conditions. The intake plateau was predicted by the equations 1.1 and 2.1, when average daily gain was in the range from 1.64 to $1.50 \mathrm{~kg} \cdot \mathrm{d}^{-1}$, corresponding to $108.4 \mathrm{e} 100.3 \mathrm{~g} / \mathrm{kg} \mathrm{BW}^{0.75}$ (equation 1.1) and $106.64 \mathrm{e} 99.04 \mathrm{~g} / \mathrm{kg} \mathrm{BW}^{0.75}$ (equation 2.1) for steer of 200 and $400 \mathrm{~kg}$, respectively.

The three phases of dry matter intake (Figure 1) support the concept that quadratic equations allow better fitting of dry matter intake prediction. When dry matter intake reaches plateau, it is likely that the demanded level of energy in the diet results in metabolic mechanisms that inhibit additional dry matter intake.

Residual feed intake is an index that can be used to calculate the efficiency of an animal (Archer et al., 1999). The residual feed intake value for each animal was calculated as the difference between the actual and the expected intake. The expected feed intake used by several researchers was calculated by the regression of the actual intake on average daily gain and metabolic weight (Kolath et al., 2006). Therefore, when the energy concentration of the diet is not available for dry matter intake prediction, it could be replaced by the average daily gain. Despite of being a characteristic of the animal that affects the dry matter intake, the average daily gain accounts for direct effects of diet that can limit intake by simplifying the model and avoiding the use of variables with practical difficulties and with cumulative mistakes in its determination such as NEm.

Including body weight and average daily gain in the equations could account for several factors that are related to the voluntary intake, thus this method can be used to
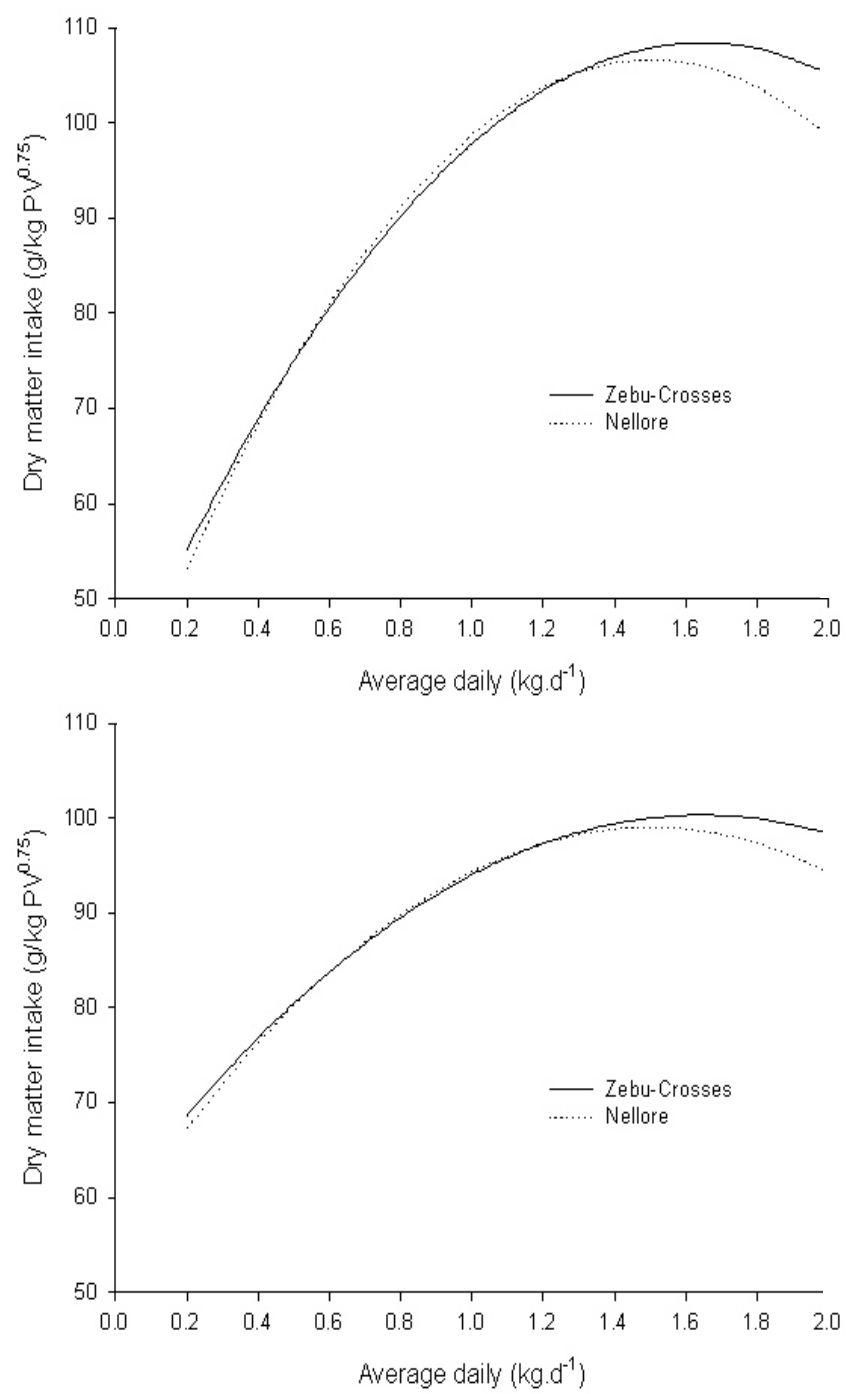

Figure 1 - Simulation of the prediction of dry matter intake for steers with average body weight of 200 (above) and $400 \mathrm{~kg}$ (down), and different average daily gain $\left(\mathrm{kg} \cdot \mathrm{d}^{-1}\right)$, using the adjusted equations 1.1 and 2.1 (Table 4 ).

Table 4 - Solution of the fixed effects of the regression equations obtained to Nellore cattle, purebred and Zebu-crosses

\begin{tabular}{|c|c|c|c|c|c|}
\hline Number & Equation & AIC & $\mathrm{BIC}$ & $\mathrm{R}^{2}$ & Genetic group \\
\hline 1.11 .2 & $\begin{array}{l}\mathrm{DMI}=-2.6098+0.08844 \mathrm{BW}^{0.75}+4.4672 \mathrm{ADG}-1.3579 \mathrm{ADG}^{2} \mathrm{DMI}= \\
-1.0094+0.01608 \mathrm{BW}+4.4363 \mathrm{ADG}-1.2548 \mathrm{ADG}^{2}\end{array}$ & 399.7395 .6 & 402.5397 .7 & 0.740 .75 & Zebu-cross \\
\hline .12 .2 & $\begin{array}{l}\mathrm{DMI}=-2.7878+0.08789 \mathrm{BW}^{0.75}+5.0487 \mathrm{ADG}-1.6835 \mathrm{ADG}^{2} \mathrm{DMI}= \\
-1.3559+0.0159 \mathrm{BW}+5.6397 \mathrm{ADG}-1.8494 \mathrm{ADG}^{2}\end{array}$ & 792.7787 .7 & 796.7791 .7 & 0.760 .79 & Nellore \\
\hline
\end{tabular}

$\mathrm{AIC}=$ Akaike information criterion BIC $=$ Bayesian information criterion. 

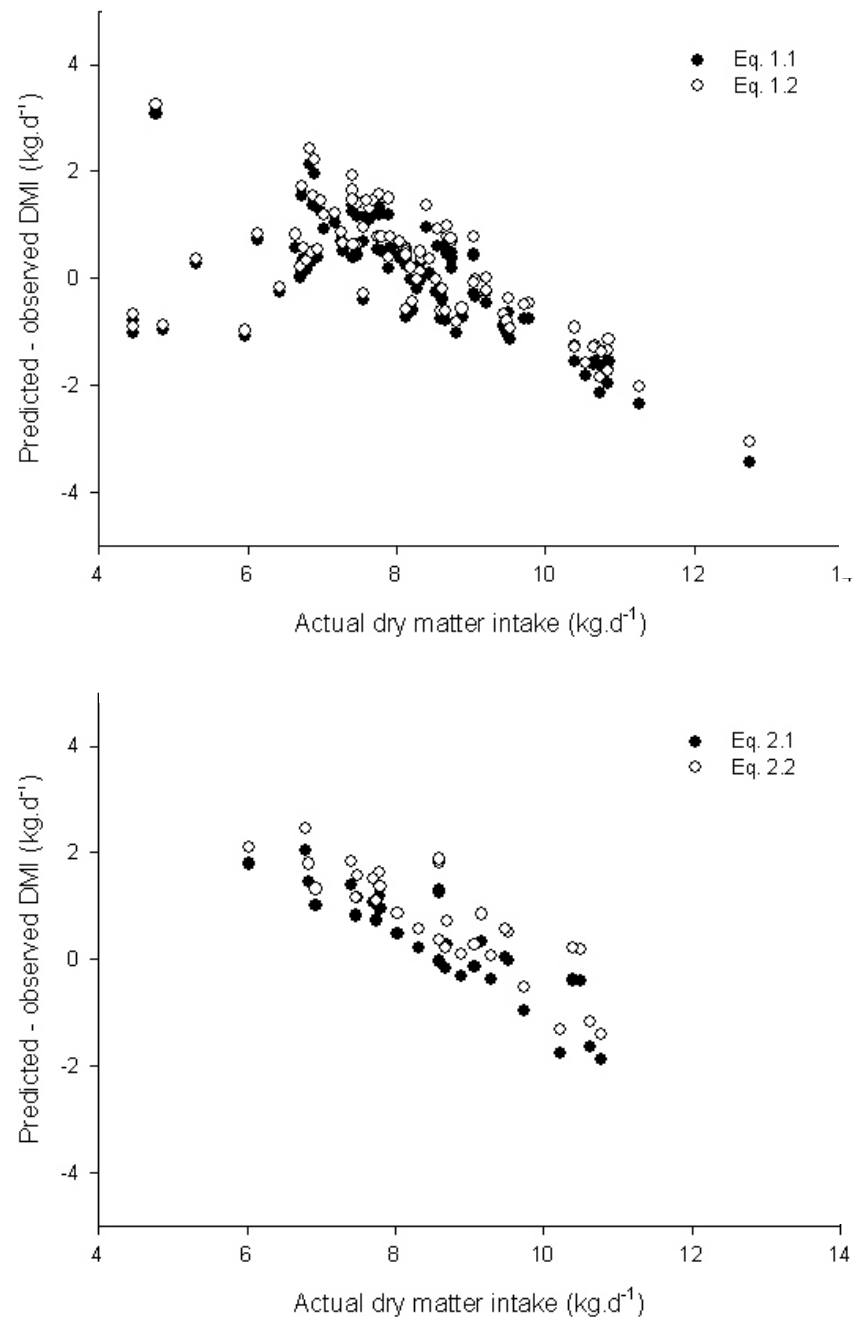

Figure 2 - The relationship between actual dry matter intake and error (predicted minus observed DMI) using fitting equations. simplify dry matter intake predictions in practical conditions.

To evaluate the equations to dry matter intake prediction proposed in this study, it was used an independent dataset obtained from experiments conducted with Zebu-crosses and Nellore cattle (Table 5).

The analysis of residuals (Figure 2) is important in order to identify data points that cause departures of the assumptions considered in linear regression (Tedeschi, 2006). The predictions for Nellore cattle overestimated dry matter intake when it was smaller than 7 or greater than $10 \mathrm{~kg} \cdot \mathrm{d}^{-1}$; nonetheless, the predicted dry matter intake for both equations were close to the equality line (Figure 2). For Zebu-crosses cattle, dispersions of $3 \mathrm{~kg} \cdot \mathrm{d}^{-1}$ were observed when extreme intakes were considered.

Yungblut et al. (1981) suggested that overestimation of dry matter intake has more serious consequences for ration formulation than does underestimation. If beef cattle eat less than what was predicted, their total nutrient intake could be lesser than the amount required toreach its potential performance. However, dry matter intake underestimation could be worse when feed costs are considered by decision support models; this is because feed costs would be underestimated, and predictions for profitability would be erroneously high. In contrast, overestimation of feed cost could result in more conservative decisions, and alternatives evaluated as profitable could be more favorable than expected.

The slope and intercept of the regression of observed and predicted by the equation that does not include metabolic body weight were significantly different than

Table 5 - Descriptive statistics of dataset used on the evaluation of DMI prediction for Zebu-crosses $(\mathrm{n}=90)^{1}$ and Nellore $(\mathrm{n}=30)^{2}$

\begin{tabular}{|c|c|c|c|c|c|c|c|}
\hline Variable & Genetic group & Minimum & Maximum & Mean & Median & Mode & SEM \\
\hline \multirow[t]{2}{*}{ Dry matter intake, $\left(\mathrm{kg} \cdot \mathrm{d}^{-1}\right)$} & Zebu-crosses & 4.46 & 12.74 & 8.18 & 8.13 & 7.47 & 0.163 \\
\hline & Nellore & 6.04 & 10.78 & 8.57 & 8.60 & 8.60 & 0.228 \\
\hline \multirow[t]{2}{*}{ Intial body weight $(\mathrm{kg})$} & Zebu-crosses & 181.20 & 422.91 & 312.78 & 314.30 & 219.30 & 5.982 \\
\hline & Nellore & 296.00 & 438.00 & 377.55 & 384.75 & 339.80 & 6.057 \\
\hline \multirow[t]{2}{*}{ Final body weight (kg) } & Zebu-crosses & 221.60 & 578.77 & 441.91 & 451.06 & 434.00 & 6.779 \\
\hline & Nellore & 424.00 & 536.00 & 476.66 & 471.25 & 465.00 & 5.110 \\
\hline \multirow[t]{2}{*}{ Body weight $(\mathrm{kg})$} & Zebu-crosses & 202.26 & 474.46 & 377.39 & 391.21 & \#N/D & 5.714 \\
\hline & Nellore & 373.00 & 487.00 & 427.11 & 424.68 & \#N/D & 5.062 \\
\hline \multirow[t]{2}{*}{ Metabolicbody weight $(\mathrm{kg})$} & Zebu-crosses & 53.63 & 101.66 & 85.44 & 87.96 & 87.67 & 1.004 \\
\hline & Nellore & 84.88 & 103.67 & 93.92 & 93.55 & \#N/D & 0.833 \\
\hline \multirow[t]{2}{*}{ Dry matter intake (\%body weight) } & Zebu-crosses & 1.06 & 2.70 & 2.16 & 2.19 & 2.27 & 0.032 \\
\hline & Nellore & 1.37 & 8.67 & 2.67 & 2.07 & 2.06 & 0.359 \\
\hline \multirow[t]{2}{*}{ Average dailygain $\left(\mathrm{kg} \cdot \mathrm{d}^{-1}\right)$} & Zebu-crosses & 0.14 & 2.15 & 1.20 & 1.23 & 0.94 & 0.037 \\
\hline & Nellore & 0.75 & 1.53 & 1.11 & 1.10 & 1.10 & 0.047 \\
\hline \multirow[t]{2}{*}{ Days on feeding (day) } & Zebu-crosses & 63.00 & 149.00 & 102.64 & 105.00 & 84.00 & 2.016 \\
\hline & Nellore & 70.00 & 133.00 & 91.93 & 86.00 & 86.00 & 3.519 \\
\hline
\end{tabular}

\#N/D, not defined.

${ }^{1}$ Zebu-crosses: Aferri et al. (2005); Chizzotti et al. (2005); Mendes et al. (2005); Pacheco et al. (2005); Silva et al. (2005); Alleoni et al.( 2006); Faturi et al. (2006); Gesualdi et al.(2006); Paixão et al. (2006); Restle et al. (2006); Souza et al. (2006a); Souza et al. (2006b); Fernandes et al. (2007); Henrique et al. (2007); Macitelli et al. (2007); Maldonado et al. (2007); Neumann et al. (2007); Pereira et al. (2007); Restle et al. (2007); Ribeiro et al. (2007); Rodrigues et al. (2007); Goulart et al. (2008) ${ }^{2}$ Nellore: Chizzotti et al. (2005); Ezequiel et al. (2006a); Ezequiel et al.(2006b); Gesualdi Junior et al. (2006); Obeid et al. (2006); Silva et al. (2007); Coan et al. (2008); Goulart et al. (2008). 
Table 6 - Statistics from regression of observed dry matter intake on dry matter intake predicted by developed equations in the evaluation data set

\begin{tabular}{|c|c|c|c|c|}
\hline \multirow[t]{3}{*}{ Item } & \multicolumn{4}{|c|}{ Genetic group } \\
\hline & \multicolumn{2}{|c|}{ Zebu-crosses } & \multicolumn{2}{|c|}{ Nellore } \\
\hline & Eq. 1.1 & Eq. 1.2 & Eq. 2.1 & Eq. 2.2 \\
\hline Intercept (a) & $0.568 \pm 0.587$ & $0.671 \pm 0.569$ & $-2.769 \pm 2.418$ & $-2.111 \pm 2.177$ \\
\hline Slope (b) & $0.930 \pm 0.077$ & $0.891 \pm 0.073$ & $1.276 \pm 0.269$ & $1.145 \pm 0.231$ \\
\hline$P$ value $($ Ho: $a=0 \& b=1)$ & 0.780 & 0.061 & 0.186 & 0.001 \\
\hline$r^{2}$ & 0.498 & 0.504 & 0.349 & 0.362 \\
\hline Root MSE, kg & 1.102 & 1.095 & 1.025 & 1.015 \\
\hline Mean absolute error $|\mathrm{Y}-\mathrm{X}| \mathrm{kg}$ & 0.872 & 0.922 & 0.853 & 1.052 \\
\hline Mean bias $(Y-X)$ & -0.006 & -0.244 & -0.317 & -0.757 \\
\hline Mean square error of prediction, $\mathrm{kg}^{2}$ & 1.194 & 1.250 & 1.106 & 1.543 \\
\hline \multicolumn{5}{|l|}{ MSEP decomposition } \\
\hline Mean bias, $\%$ & 0.003 & 4.745 & 9.096 & 37.123 \\
\hline Systematic bias, \% & 0.560 & 1.413 & 2.223 & 0.569 \\
\hline Random errors, \% & 99.437 & 93.842 & 88.681 & 62.308 \\
\hline \multicolumn{5}{|c|}{ Concordance correlation coefficient (CCC) } \\
\hline $\mathrm{R}$ & 0.680 & 0.681 & 0.428 & 0.385 \\
\hline Location shift (u) & -0.004 & -0.177 & -0.373 & -0.836 \\
\hline Bias correction $(\mathrm{Cb})$ & 0.963 & 0.960 & 0.724 & 0.639 \\
\hline
\end{tabular}

unity and zero, respectively $(\mathrm{P}>.10)$, indicating that these equations are not appropriate to predict dry matter intake in tropical conditions. However, for the equation that included metabolic body weight, the intercept did not differ from zero and the slope did not differ from 1 (Table 6).

All equations resulted in an overprediction of dry matter intake mean due to negative mean bias and location shift (u). For both Zebu-Crosses and Nellore cattle, the prediction equations that included metabolic body weight were more precise. These equations had a slight advantage over the equation using body weight if mean square prediction error, mean absolute error, and mean bias were evaluated.

The partition of mean square prediction error into threecomponents revealed that random errors appear to be the major cause of inaccuracy in the dry matter intake prediction. Additionally, equation 2.2 for Nellore cattle, which did not include metabolic body weight, had a mean bias value larger than $37 \%$ of the observed dry matter intake mean. Yungblut et al. (1981) considered a mean bias smaller than $10 \%$ of the actual dry matter intake mean as acceptable; this condition was in agreement for equations $1.1 ; 1.2$ and 2.1 , which had values of, $0.003 ; 4.745$ and $9.096 \%$ respectively.

When the correlation concordance coefficient ( $r, u$ and $\mathrm{Cb}$ ), which consists of a measure of precision and accuracy, was analyzed, the best fitting equation to dry matter intake prediction was those including metabolic body weight in the model. The equation used for dry matter intake prediction of Zebu-crosses beef cattle had a location shift (u) close to zero, and a bias correction $(\mathrm{Cb})$ very close to 1 , as well as a high $r$, indicating that this was the most precise and accurate model.

\section{Conclusions}

A single equation should not be used to predict dry matter intake for beef cattle in tropical conditions, because there are differences between Zebu and Zebu-crosses. Equations that include average daily gain and metabolic body weight should be used as an alternative method to predict dry matter intake of Zebu-crosses and Nellore beef cattle in tropical conditions.

\section{References}

AFERRI, G.; LEME, P.R.; SILVA, S.L. et al. Desempenho e características de carcaça de novilhos alimentados com dietas contendo diferentes fontes de lipídios. Revista Brasileira de Zootecnia, v.34, n.5, p.1651-1658, 2005.

ALBUQUERQUE, S.G. Cana-de-açúcar, palha de feijão e silagem de sorgo em associação com melaço-uréia para novilhos em confinamento. 1972. 41f. Dissertação (Mestrado em Zootecnia) - Universidade Federal de Viçosa, Viçosa, MG.

ALLEONI, G.F.; BOIN, C.; BEISMAN, D.A. Utilização de diferentes suplementos no desempenho de bovinos alimentados com dietas básicas de cana-de-açúcar. Boletim de Indústria Animal, v.63, p. $165-175,2006$.

ARCHER, J.A.; RICHARDSON, E.C.; HERD, R.M. et al. Potential for selection to improve efficiency of feed use in beef cattle: a review. Australian Journal of Agricultural Research, v.50, n.2, p.147-162, 1999.

BACKES, A.A. Composição corporal e exigências de energia, proteína e macroelementos minerais, para bovinos mestiços leiteiros e zebu, castrados, em fase de recria e engorda, em confinamento. 2003. 100f. Tese (Doutorado em Zootecnia) - Universidade Federal de Viçosa, Viçosa, MG.

CHIZZOTTI, F.H.M.; PEREIRA, O.G.; VALADARES FILHO, S.C. et al. Consumo, digestibilidade total e desempenho de novilhos Nelore recebendo dietas contendo diferentes proporções de silagens de Brachiaria brizantha cv. Marandu e de sorgo. Revista Brasileira de Zootecnia, v.34, n.6, p.2427-2436, 2005. 
CHIZZOTTI, M.L. Exigências nutricionais de bovinos nelore, puros e cruzados, de diferentes classes sexuais. 2007. 118f. Tese (Doutorado em Zootecnia) - Universidade Federal de Viçosa, Viçosa, MG.

COAN, R.M.; REIS, R.A.; RESENDE, F.D. et al. Viabilidade econômica, desempenho e características de carcaça de garrotes em confinamento alimentados com dietas contendo silagem de capins tanzânia ou marandu ou silagem de milho. Revista Brasileira de Zootecnia, v.37, p.311-318, 2008.

DRAPER, N.R.; SMITH, H. Applied regression analysis. 2.ed. New York: John Wiley \& Sons Co., 1981. 709p.

EZEQUIEL, J.M.B.; SILVA, L.D.F.; AZEVEDO, P.S. et al. Uso da cutina na estimativa das digestões total e parcial de alguns componentes de rações contendo diferentes fontes de nitrogenio, em bovinos. Revista Brasileira de Zootecnia, v.35, n.2, p.600-606, 2006a.

EZEQUIEL, J.M.B.; SILVA, O.G.C.; GALATI, R.L. et al. Desempenho de novilhos Nelore alimentados com casca de soja ou farelo de gérmen de milho em substituição parcial ao milho moído. Revista Brasileira de Zootecnia, v.35, n.2, p.569-575, 2006 b.

FATURI, C.; EZEQUIEL, J.M.B.; FONTES, N.A. et al. Fibra solúvel e amido como fontes de carboidratos para terminação de novilhos em confinamento. Revista Brasileira de Zootecnia, v.35, n.5, p.2110-2117, 2006.

FERNANDES, A.R.M.; HENRIQUE, W.; SAMPAIO, A.A.M. et al Avaliação econômica e desempenho de machos e fêmeas Canchim confinados, recebendo dietas com silagem de milho ou com cana-de-açúcar e grãos de girassol. Revista Brasileira de Zootecnia, v.34, n.4, p.855-864, 2007.

FERNANDES, H.J. Desempenho produtivo, digestibilidade e composição corporal de bovinos de três grupos genéticos na recria e na terminação. 2001. 72f. Dissertação (Mestrado em Zootecnia) - Universidade Federal de Viçosa, Viçosa, MG.

FOX, D.G.; JOHNSON, R.R.; PRESTON, R.L. et al. Protein and energy utilization during compensatory growth in beef cattle. Journal of Animal Science, v.34, p.310-318, 1972.

GALVÃO, J.G.C. Estudo da eficiência nutritiva, características e composição física da carcaça de bovinos de três grupos raciais, abatidos em três estágios de maturidade. 1991. 82f. Dissertação (Mestrado em Zootecnia) - Universidade Federal de Viçosa, Viçosa, MG.

GESUALDI JR., A. Níveis de concentrado na dieta de novilhos F1 Limousin $x$ Nelore em confinamento: desempenho produtivo e características de carcaça. 1999. 62f. Dissertação (Mestrado em Zootecnia) - Universidade Federal de Viçosa, Viçosa, MG.

GESUALDI JR., A.; QUEIROZ, A.C.; RESENDE, F.D. et al Desempenho produtivo e eficiência bioeconômica de bovinos Nelore e Caracu selecionados para peso aos 378 dias de idade recebendo alimentação à vontade ou restrita. Revista Brasileira de Zootecnia, v.35, n.2, p.576-583, 2006

GOULART, R.S.; ALENCAR, M.M.; POTT, E.B. et al. Composição corporal e exigências líquidas de proteína e energia de bovinos de quatro grupos genéticos terminados em confinamento. Revista Brasileira de Zootecnia, v.37, n.5, p.926-935, 2008

HENRIQUE, W.; BELTRAME FILHO, J.A.; LEME, P.R. et al. Avaliação da silagem de grãos de milho úmido com diferentes volumosos para tourinhos em terminação. Desempenho e características da carcaça. Revista Brasileira de Zootecnia, v.36, n.1, p.183-190, 2007.

JONES, S.D.M. Carcass tissue yield and distribution in three biological types of cattle fed grain or forage based diets. Canadian Journal of Animal Science, v.65, p.363-372, 1985.

JORGE, A.M. Ganho de peso, conversão alimentar e características da carcaça de bovinos e bubalinos. 1993. 97f. Dissertação (Mestrado em Zootecnia) - Universidade Federal de Viçosa, Viçosa, MG.
KOLATH, W.H.; KERLEY, M.S.; GOLDEN, J.W. et al. The relationship between mitochondrial function and residual feed intake in Angus steers. Journal of Animal Science, v.84, p.861-865, 2006.

LEONEL, F.P. Exigências nutricionais em macronutrientes minerais ( Ca, P, Mg, Na e K) para novilhos de diferentes grupos zootécnicos. 2003. 53f. Dissertação (Mestrado em Zootecnia) - Universidade Federal de Viçosa, Viçosa, MG.

LIN, L.I.K. A concordance correlation coefficient to evaluate reproducibility. Biometrics, v.45, p.255-268, 1989.

LORENZONI, W.R. Estudos sobre eficiência nutritiva e qualidade da carcaça de diverso genéticos de bovídeos. 1984. 51f. Dissertação (Mestrado em Zootecnia) - Universidade Federal de Viçosa, Viçosa, MG.

MACITELLI, F.; BERCHIELLI, T.T.; MORAIS, J.A.S. et al. Desempenho e rendimento de carcaça de bovinos mestiços alimentados com diferentes volumosos e fontes protéicas. Revista Brasileira de Zootecnia, v.36, n.6, p. 1917-1926, 2007

MALDONADO, F.; QUEIROZ, A.C.; ALLEONI, G.F. et al. Desempenho e características da carcaça de bovinos de dois grupos genéticos, terminados em confinamento e abatidos com diferentes pesos. Boletim de Indústria Animal, v.64, p.9-18, 2007

MARCONDES, M.I. Desempenho de bovinos nelore alimentados individualmente ou em grupo, exigências nutricionais e avaliação protéica de alimentos para ruminantes. 2007. 152f. Dissertação (Mestrado em Zootecnia) - Universidade Federal de Viçosa, Viçosa, MG.

MARCONDES, M.I. Exigência nutricionais e avaliação econômica de bovinos Nelore, Nelore-Angus e NeloreSimental em dietas com alto ou baixo nível de concentrado. 2010. Tese (Doutorado em Zootecnia) Universidade Federal de Viçosa, Viçosa, MG.

MARGON, A.L. Requerimento de macrominerais (Ca, P, Mg, Na e K) para engorda de novilhos Zebu . 1981. 74f. Dissertação (Mestrado em Zootecnia) - Universidade Federal de Viçosa, Viçosa, MG.

MAYER, D.G.; BUTLER, D.G. Statistical validation. Ecological modelling, v.68, p.21-32, 1993.

MAYER, D.G.; STUART, M.A.; SWAIN, A.J., 1994. Regression of real-world data on model output: an appropriate overall test of validity. Agricultural Systems, v.45, p.93-104, 1994.

MENDES, A.R.; EZEQUIEL, J.M.B.; GALATI, R.L. et al Desempenho, parâmetros plasmáticos e características de carcaça de novilhos alimentados com farelo de girassol e diferentes fontes energéticas, em confinamento. Revista Brasileira de Zootecnia, v.34, n.2, p.692-702, 2005.

MENEZES, L.F.G.; RESTLE, J. Desempenho de novilhos de gerações avançadas do cruzamento alternado entre as raças charolês e nelore, terminados em confinamento. Revista Brasileira de Zootecnia, v.34, n.6, p.1927-1937, 2005.

MERTENS, D.R. Regulation of forage intake. In:FAHEY JR., G.C.; COLLINS, M.; MERTENS, D.R. et al. (Eds.) Forage quality, evaluation and utilization. Madison: American Society of Agronomy, Crop Science of America, Soil Science of America, p.450-493, 1994.

MIRANDA. E.N. Composição corporal e exigências de macroelementos minerais ( $\mathrm{Ca}, \mathrm{P}, \mathrm{Mg}$, $\mathrm{Na}$, e $\mathrm{K}$ ) de bovinos Nerole e Caracu selecionados para peso aos 378 dias de idade. 2005. 86f. Dissertação (Mestrado em Zootecnia) Universidade Federal de Viçosa, Viçosa, MG.

NEUMANN, M.; MUHLBACH, P.R.F.; NORNBERG, J.L. Efeito do tamanho de partícula e da altura de colheita das plantas de milho (Zea mays L.) para ensilagem na produção do novilho superprecoce. Revista Brasileira de Zootecnia, v.36, n.5, p.1614-1623, 2007 (supl.).

NATIONAL RESEARCH COUNCIL - NRC. Nutrient requirements of beef cattle. updated 7.ed. Washington, DC.: National Academy Press, 2000. 
NATIONAL RESEARCH COUNCIL - NRC. Beef cattle. In Predicting feed intake of food-producing animals. Washington, D.C., 1987. p.56-74.

OBEID, J.A.; PEREIRA, O.G.; PEREIRA, D.H.; et al. Níveis de proteína bruta em dietas de bovinos de corte: consumo, digestibilidade e desempenho produtivo. Revista Brasileira de Zootecnia, v.35, n.6, p.2434-2442, 2006.

OLIVEIRA, S.R. Desempenho e características da carcaça de novilhos Nelore não castrados. 1998. 58f. Dissertação (Mestrado em Zootecnia) - Universidade Federal de Viçosa, Viçosa, MG.

PACHECO, P.S.; RESTLE, J.; SILVA, J.H.S. Desempenho de novilhos jovens e superjovens de diferentes grupos genéticos terminados em confinamento. Revista Brasileira de Zootecnia, v. 34 , n.3, p.963-975, 2005.

PAIXÃO, M.L.; VALADARES FILHO, S.C.; LEÃO, M.I. et al. Uréia em dietas para bovinos: consumo, digestibilidade dos nutrientes, ganho de peso, características de carcaça e produção microbiana. Revista Brasileira de Zootecnia, v.35, n.6, p.2451-2460, 2006.

PAULINO, M.F. Composição corporal e exigências de energia proteína e macroelementos minerais ( $\mathrm{Ca}, \mathrm{P}, \mathrm{Mg}$ e $\mathrm{K}$ ) de bovinos não castrados de quatro raças zebuínas. 1996. 80f. Tese (Doutorado em Zootecnia) - Universidade Federal de Viçosa, Viçosa, MG.

PAULINO, P.V.R. Desempenho, composição corporal e exigências nutricionais de bovinos Nelore de diferentes classes sexuais. 2006. 183f. Tese (Doutorado em Zootecnia) Universidade Federal de Viçosa, Viçosa, MG.

PAULINO, P.V.R. Exigências nutricionais e validação da seção HH para predição da composição corporal de zebuínos. 2002. 150f. Dissertação (Mestrado em Zootecnia) - Universidade Federal de Viçosa, Viçosa, MG.

PEREIRA, E.M.; SANTOS, F.A.P.; NUSSIO, L.G. et al. Estimativa de energia metabolizável de rações com polpa cítrica em substituição ao milho para tourinhos em terminação. Revista Brasileira de Zootecnia, v.36, n.1, p.216-224, 2007.

PERON, A.J. Características e composição física e química, corporal e da carcaça de bovinos de cinco grupos genéticos, submetidos a alimentação restrita e "ad libitum". Viçosa, MG: Universidade Federal de Viçosa, 1991. 126f. Dissertação (Mestrado em Zootecnia) - Universidade Federal de Viçosa, 1991.

PICARD, R.R.; COOK, R.D. Cross-validation of regression models. Journal of the American Statistical Association, v.79, p.575-583, 1984.

PITTROFF, W.; KOTHMANN, M.M. Quantitative prediction of feed intake in ruminants II. Conceptual and mathematical analysis of models for cattle. Livestock Production Science, v.71, p. 151-169, 2001.

PLEGGE, S.D.; GOODRICH, R.D.; HANSEN, S.A. et al. Predicting dry matter intake of feedlot cattle. Minnesota, 1984. 56p.

PUTRINO, S.M. Exigências de proteína e energia líquidas para o ganho de peso de tourinhos das raças Nelore e Brangus alimentados com dietas com diferentes proporções de concentrado. 2002. 82f. Dissertação (Mestrado em Zootecnia - Qualidade e Produtividade Animal) - Universidade de São Paulo, Pirassununga.

RESENDE, F.D. Avaliação de diferentes proporções de volumoso: concentrado sobre a ingestão, digetibilidade, ganho de peso e conversão alimentar de bovinos mestiços confinados. 1999. 78f. Tese (Doutorado em Zootecnia) - Universidade Federal de Viçosa, Viçosa, MG.

RESTLE, J.; PACHECO, P.S.; ALVES FILHO, D.C. et al. Silagem de diferentes híbridos de milho para produção de novilhos superjovens. Revista Brasileira de Zootecnia, v.35, n.5, p.2066-2076, 2006

RIGUEIRA, J.P.S. Silagem de soja na alimentação de bovino de corte. Viçosa, MG: Universidade Federal de Viçosa, 2007. 63f. Dissertação (Mestrado em Zootecnia) - Universidade Federal de Viçosa, 2007.
RODRIGUES, K.K.N.L.; ROSSI JR., P.; MOLETTA, J.L. et al. Avaliação do desempenho de bovinos mestiços Purunã alimentados com diferentes níveis de energia. Boletim de Indústria Animal, v.64, p.241-247, 2007.

ROSELER, D.K.; FOX, D.G.; CHASE, L.E. et al. Development and evaluation of equations for prediction of feed intake for lactating Holstein dairy cows. Journal of Dairy Science, v.80, p.878-893, 1997.

SALVADOR, M. Exigência de energia e proteína para engorda de novilhos azebuados. 1980. 70f. Dissertação (Mestrado em Zootecnia) - Universidade Federal de Viçosa, Viçosa, MG.

SHAH, M.A.; MURPHY, M.R. Development and evaluation of models to predict the feed intake of dairy cows in early lactation. Journal of Dairy Science, v.89, p.294-306, 2006.

SILVA, B.C.; PEREIRA, O.G.; PEREIRA, D.H.; et al. Consumo e digestibilidade aparente total dos nutrientes e ganho de peso de bovinos de corte alimentados com silagem de Brachiaria brizantha e concentrado em diferentes proporções. Revista Brasileira de Zootecnia, v.34, n.3, p.1060-1069, 2005.

SILVA, F.F. Desempenho, características de carcaça, composição corporal e exigências nutricionais (de energia, proteína, aminoácidos e macrominerais) de novilhos Nelore, nas fases de recria e engorda, recebendo diferentes níveis de concentrado e proteína. 2001. 211f. Tese (Doutorado em Zootecnia) - Universidade Federal de Viçosa, Viçosa, MG.

SILVA, S.L.; LEME, P.R.; PUTRINO, S.M. et al. Milho grão seco e úmido e sais de cálcio de ácidos graxos para novilhos nelore em confinamento. Revista Brasileira de Zootecnia, v.36, p.1426-1434 2007.

SOUZA, V.G.; PEREIRA, O.G.; VALADARES FILHO, S.C. et al. Efeito da substituição de pré-secado de capim-tifton 85 por silagem de sorgo no consumo e na digestibilidade dos nutrientes e no desempenho de bovinos de corte. Revista Brasileira de Zootecnia, v.35, n.6, p.2479-2486, 2006.

SOUZA, V.G.; PEREIRA, O.G.; VALADARES FILHO, S.C.; Efeito da substituição de feno de capim-tifton 85 por silagem de milho no consumo, na digestibilidade dos nutrientes e no desempenho de novilhos mestiços Limousin. Revista Brasileira de Zootecnia, v.35, n.5, p.2172-2178, 2006.

ST-PIERRE, N.R. Invited review: Integrating quantitative findings from multiple studies using mixed model methodology. Journal of Dairy Science, v.84, p.741-755, 2001.

TEDESCHI, L.O. Assessment of the adequacy of mathematical models: Review. Agricultural Systems, v.89, p.225-247, 2006.

TEIXEIRA, J.C. Exigências de energia e proteína, composição e área corporal e principais corte de carcaça em seis grupos genéticos de bovídeos. 1984. 94f. Tese (Doutorado em Zootecnia) - Universidade Federal de Viçosa, Viçosa, MG.

THORNTON, J.H.; OWENS, E.N.; GILL, D.R. Feed intake by feedlot beef steers: Influence of initial weight and time on feed. Oklahoma Agricultural Experiment Station Reseacrh Report MP-117, 320, 1985.

VELOSO, C.M. Composição corporal e exigências nutricionais de bovinos F1 Limousin $\times$ Nelore alimentados com rações contendo diferentes níveis de concentrado . 2001. 109f. Tese (Doutorado em Zootecnia) - Universidade Federal de Viçosa, Viçosa, MG.

VÉRAS, A.S.C. Consumo, digestibilidade, composição exigências nutricionais de bovinos Nelore alimentados com rações contendo diferentes níveis de concentrado. 2000. 166f. Tese (Doutorado em Zootecnia) - Universidade Federal de Viçosa, Viçosa, MG.

VIEIRA, B.R. Silagem de capim-mombaça em diferentes proporções na dieta de bovinos de corte. 2007. $83 \mathrm{f}$. Dissertação (Mestrado em Zootecnia) - Universidade Federal de Viçosa, Viçosa, MG.

YUNGBLUT, D.H.; STONE, J.B.; MACLEOD, G.K. et al. The testing of several feed intake prediction equations using farm data. Canadian Journal of Animal Science, v.61, p.159-164, 1981. 